\title{
Reversing the Wave: \\ The Perverse Effects of Economic Liberalism on Human Rights
}

\author{
UMUT KORKUT* \\ University College Dublin
}

\begin{abstract}
This article takes the conservative shift in Polish politics under PiS as an example and argues that the failure of the liberal economy could end up reversing the fast-forward wave in human rights. And because Poland is a relatively new member of the EU, the article also develops the argument that such a reversal in the new member countries could make the European Union's (EU) acquis irrelevant for further democratisation. Therefore, the article first explains how the failure of the economic liberalism of the neo-liberal market economy paves the way for the success of conservative political parties. It then raises the question of why political liberalism, promoted by the EU's human rights acquis, is also a target for the opponents of the market economy. The article concludes with a discussion of current Polish politics in the aftermath of the October 2007 elections.
\end{abstract}

Keywords: liberalism, Poland, PiS, EU, human rights

Sociologický časopis/Czech Sociological Review, 2009, Vol. 45, No. 3: 571-590

\section{Introduction}

Is it possible for economic liberalisation to lead to the contraction of civil rights? This article looks at the conservative shift in Polish politics under the PiS (Prawo a sprawiedliwość - Law and Justice Party) government from September 2005 to October 2007 in Poland as an example and argues that the failure of liberal economy could end up reversing the fast-forward wave in human rights. Therefore, rather than explaining the ascendance of PiS purely as a result of embedded conservatism in Polish politics, the article depicts how conservative political parties can oppose economic and political liberalism in one package. Given that Poland is a relatively new member of the European Union (EU), this article also develops a subsidiary argument, that such a reversal in the new member countries could weaken EU accession criteria as a tool for democratisation.

The Polish picture has repercussions beyond Poland. More recently, political conservatism has also found resonance in other countries of 'new' Europe. There are signs in Hungary, Latvia, and Slovakia that the conservative and populist po-

\footnotetext{
* Direct all correspondence to: Umut Korkut, University College Dublin, School of Politics and International Relations, Dublin 4, Republic of Ireland, e-mail: umut.korkut@ucd.ie.
} 
litical forces of 'new' Europe remain suspicious of extended rights and freedoms, despite the EU's extensive legislation in the fields of anti-discrimination, equality, and freedom of expression. The 2006 elections in Hungary saw numerous references to the PiS victory in Poland. The leader of the opposition Fidesz, Viktor Orbán, on numerous occasions mentioned that PiS in Poland had prepared the scenario for Hungary to follow [Korkut 2007]. What started with PiS is that populist parties in the new EU member states have begun to assess the regime change since 1989 as corrupt, degenerate, and unsuccessful. In order to fix the mistakes of transformation, these parties offer themselves as conservative alternatives, not only regarding economic liberalism but also political liberalism.

In this respect, this article offers the following argument regarding the Europeanisation of human rights in the new member states. It is clear that EU membership is an important incentive for reform in the EU accession states. To this end, Schimmelfennig, Engert and Knobel [2003] showed that the material benefits embedded in membership make the accession countries carry out impressive reforms fast and swiftly. Cortell and Davis [2005: 4] argued that the EU accession states constituted a weak test of how international norms can change state behaviour through processes of internalisation, since strong material incentives were embedded in the EU accession process. In contrast to both of these approaches, the article argues that two contingent factors of transition in Poland, such as Polish Catholicism and economic liberalism, react to and interact with the process of institutionalisation in a complex way. Thus, introducing market reforms can be a means of qualifying for EU accession, but at the same time they pave the way to political problems if they instigate corruption scandals and wide social inequalities and bring poverty to those who lack the necessary skills to catch up with the requirements of competitive economic systems. This is how the paper assesses the failure of the economic liberalism that was institutionalised in the new member states.

This article has four parts. The first section sets out the background factors that influenced the ascendancy of PiS. In the second section, I elaborate on manifestations of this conservative shift in Poland - namely, the election of PiS and its policies towards women's and gay rights and freedom of the press - as examples of the diminishing civil rights in Poland. The conclusion summarises the argument put forth in the article and restates its wider implications for further research.

\section{The background to the ascendancy of PiS}

In September 2005, with an electoral turnout barely above $40 \%$, the Poles gave the majority of their votes to a centre-right party called PiS headed by the twins Jarosław and Lech Kaczyński. The party is based on Catholic, anti-communist, and conservative values. A month after this victory, in the second round of sepa- 
rate presidental elections, the electoral turn-out was just above $50 \%$. The majority of those who actually bothered to vote chose the PiS candidate Lech Kaczyński. The populist Samoobrona (Self-Defense Movement) and the nationalist Catholic right-wing LPR (League of Polish Families) also entered the Sejm with, respectively, $11.4 \%$ and $8 \%$ of the votes. These two parties entered into a coalition government with PiS in May 2006 after a brief period of supporting PiS in a minority government. These three parties were able to unite in their shared opposition to economic and social liberalism and suspicion of the European Union [Garton Ash 2006; McManus-Czubińska et. al. 2003].

While PiS and its allies were subsequently defeated in the 2007 election by PO (Civic Platform), it still left an important legacy for Polish politics in particular and Central and East European politics in general. Its overtly anti-liberal stance towards human rights and its portrayal of the economic and political liberalisation of the transition years as the reason for the moral problems of Poland maintain this legacy. Furthermore, despite losing to the PO by 10 percentage points, votes for PiS were up by 6 percentage points from 2005. The increase in turnout between the 2005 and 2007 elections (when turnout was around 54\%) partially explains the success of the PO. Also, the PO was the main beneficiary from the new voters of the post-1989 generation. It managed to secure 2.5 million votes from voters who had not participated in the previous election and around 1.5 million votes from voters who switched from other, mainly leftist, parties, which helped the PO's chair, Donald Tusk, to win [Bugyinski 2006]. By the end of 2007, Donald Tusk was the prime minister of a coalition government formed between his PO and the PSL (Polish Peasant Party).

During its government, PiS promoted historical constructivist, conservative propaganda. While in office, Lech Kaczyński articulated his party's stance towards the changes in Poland since 1989, assessing them as 'degeneration' and failed transformation (HetiVálasz, 2 March 2006). In order to cure the evils of transformation, PiS politicians promoted a new orientation to politics that looks back and focuses on the past. PiS vowed to defend Polish morals against interference from the European Union and the party became critical of the morals of other EU countries. In his inaugural address, the then prime minister, Jarosław Kaczyński, defiantly declared that Poland wanted to belong to the EU, but added: 'We differ. There is no reason to hide this'. Kaczyński declared that they were 'going to work so that Poland can retain its full sovereignty in culture and morals.' These were references to the issues of abortion and women's and gay rights in Poland (International Herald Tribune, 20 July 2006). And against the human rights of the European Union, Poland presented patriotism. Thus, the PiS version of conservatism united four crucial elements in one basket: socialist economic thought, antiliberalism, Euroscepticism, and a dislike of Germany and Russia [Kosc 2005a].

Yet, how did this message attract voters in Poland? While PiS won its victory amidst the very low electoral turn-out in the 2005 elections, its road to power is still worth noting. Below, the results of CBOS (Public Opinion Research Centre) 
Table 1. Selected CBOS survey results on democracy, political liberalism, and the EU

\begin{tabular}{|c|c|c|}
\hline Early 2000s & $\begin{array}{l}\text { Towards EU } \\
\text { accession }\end{array}$ & Since 2004 \\
\hline $\begin{array}{l}\text { - February 2000: } \\
\text { Freedom is } \\
\text { important, but } \\
\text { it is excessive in } \\
\text { Poland. } \\
\text { Equality in } \\
\text { social life refers } \\
\text { to equal rights, } \\
\text { equal chances of } \\
\text { achieving a high } \\
\text { social position, } \\
\text { and similar living } \\
\text { conditions. } \\
\text { Poland is quite } \\
\text { lacking in equality. }\end{array}$ & $\begin{array}{l}\text { - September 2003: } \\
\text { The main features } \\
\text { of democracy are } \\
\text { equality before the } \\
\text { law, state guar- } \\
\text { antee of a decent } \\
\text { living by the } \\
\text { state, and equal } \\
\text { education. These } \\
\text { features do not } \\
\text { exist in Poland. }\end{array}$ & $\begin{array}{l}\text { - May 2005: No major gains from EU acces- } \\
\text { sion, a lack of better prospects for youth, } \\
\text { open markets are not beneficial. } \\
\text { - May 2006: Religious faith is more important } \\
\text { in life than freedom of speech. Homosexual- } \\
\text { ity is a deviation. } \\
\text { - April 2006: Old members gained more than } \\
\text { Poland from enlargement. Poland is an } \\
\text { important country in the EU } \\
\text { - June 2006: 34\% dissatisfied with capitalism. } \\
\text { - September 2007: Fighting corruption and } \\
\text { public safety are the most significant } \\
\text { achievements of PiS. } \\
\text { - November } 2007 \text { (end of PiS government): } \\
\text { Democracy works in Poland. }\end{array}$ \\
\hline
\end{tabular}

opinion polls in Poland from three different periods shed light on the rise of PiS in terms of respondents' feelings about democracy, freedoms, the economic system, and Poland's EU accession.

What was specific about the rise of PiS, however, was its message that the system put in place in Poland since 1989 is corrupt and has failed. And at the end of its government term, as the CBOS surveys show, those who were polled did not see any problems with the way democracy works in Poland. The respondents also noted that the fight against corruption was one of the achievements of PiS. The fight against degeneration, deviance, and corruption were, indeed, the most crucial aspects of the PiS programme. In order to depict how the corruptionfighter narrative of PiS was able to attract voters, below I present the CBOS opinion poll results on corruption and the prosperity of the elite since the late 1990s and early 2000s in Poland.

The CBOS opinion polls provide some background to PiS's ascendance to power. However, the results provide only some evidence as to how PiS could gain support by means of its sceptical standpoint on political and economic liberalism. The ascent of PiS into power had a new aspect: if traditional Catholic conservatism triggered a reaction to political liberalism, the reaction of PiS to economic liberalism forged only more conservatism. PiS succeeded in transmitting a Eurosceptical message by articulating people's concerns over a 'corruption-ridden' market economy, against which it offered a protective state that would fight against corruption and wage a moral revolution to undo the wrongdoings that 
Table 2. Selected CBOS survey results on corruption and prosperity in Poland

\begin{tabular}{|c|c|}
\hline Corruption: & Prosperity: \\
\hline - June/August 2001: & - February 1999: \\
\hline $\begin{array}{l}\text { Two-thirds of respondents believed that } \\
\text { corruption is a very big problem in Poland }\end{array}$ & $\begin{array}{l}62 \% \text { of respondents declared that the rich } \\
\text { do not deserve high social regard, because }\end{array}$ \\
\hline \multirow{3}{*}{$\begin{array}{l}70 \% \text { believed that a large percentage of } \\
\text { civil servants gain unjustified benefits from } \\
\text { their positions. The percentage of respond- } \\
\text { ents with a negative opinion of the honesty } \\
\text { of a large proportion of civil servants has } \\
\text { been growing steadily since } 1995 \text {. }\end{array}$} & $\begin{array}{l}\text { 'nowadays in Poland it is impossible to } \\
\text { make a fortune through honest work'. }\end{array}$ \\
\hline & $\begin{array}{l}\text { Power and informal relations affect peo- } \\
\text { ple's chances of prospering. }\end{array}$ \\
\hline & $\begin{array}{l}\text { The poor are ordinary people who work, } \\
\text { but earn too little to provide sufficient }\end{array}$ \\
\hline \multirow{3}{*}{$\begin{array}{l}\text { Over one-half of respondents declared that } \\
\text { the present government and the parlia- } \\
\text { mentary opposition are equally corrupt. }\end{array}$} & $\begin{array}{l}\text { financial means for themselves and their } \\
\text { families. }\end{array}$ \\
\hline & - February 2005: \\
\hline & $\begin{array}{l}\text { Privatisation benefits dishonest people, } \\
\text { fraudsters, government officials, and for- } \\
\text { eign capital. }\end{array}$ \\
\hline
\end{tabular}

had occurred since 1989. That was how inequality, corruption, and unemployment blamed on the economic liberalism of the neo-liberal transformation triggered a conservative reaction to liberalism under the banner of PiS. Yet, this new aspect of Polish politics derived from the insistence of Kaczyński and others that just about everything the past post-communist governments had done was either corrupt, infected with immoral practices, or inadequate for the defence of Poland's interests.

In this attempt, PiS reflected a sceptical position towards political liberalism especially in the areas of gender rights and freedom of expression. Its rise to power and the legacy it left behind show that PiS convinced the public of its own interpretation of the Polish transformation - or of its failure. Indicators of political liberalism are respect for individual rights and freedoms and the full application of the EU anti-discrimination agenda and safeguarding equality between different social components. It is possible to regard a political regime's view of gender rights and freedom of expression as prisms of political liberalism. However, this article does not argue that under the previous governments of Poland, political liberalism was comprehensively entrenched. The tenets of traditional Polish conservatism inevitably find space for themselves in PiS ideology. However, to restate, what is new to PiS's conservatism is the way it used the narrative of failed transformation and economic liberalism to curtail political liberties.

The article argues that the EU membership process was unable to fully entrench political liberalism in Poland, whereby the conservative political narrative 
suggested that the past political elites had not asserted Polish interests sufficiently in the EU accession process and thus membership brought forward an identity gap between Poland and the EU. This gap had repercussions that affected the implementation of both the political and economic requirements of membership. This argument rests on my normative assumption that both the economic and the political dimensions of EU membership have equal weight. This normative assumption, however, does not refute the argument that the post-accession implementation of the EU acquis can be obstructed by the political elite [Pridham 2008]. Rather than comparing the implementation of the economic and of the political acquis with each other, in the article I have chosen to illustrate how the implementation of the economic acquis and its underlying neo-liberalism led to reactions against both the political and economic acquis. In order to substantiate my point I concentrate on issues related to gender rights and freedom of expression in Poland as expressions of human rights issues. As I will demonstrate in the next section, the conservative shift in Poland was a manifestation of how the process of liberalisation, associated with the EU accession process, could lose ground in the new member states with the ascendance of conservative forces.

Before proceeding to discuss the manifestations of the conservative shift in Poland, however, I will briefly state why the left failed to become a magnet for those frustrated with economic liberalism. This discussion may also explain why the Polish context has repercussions for some other new member states, notably Hungary and Slovakia. One feature central to the Polish context is that, unlike before, the people, tired of the economic uncertainty brought about by the free market, no longer vote for the left-wing parties. In the past, the Polish Democratic Left Alliance (SLD) traditionally gained 5-6 percentage points more of the vote, when the same voters who opposed putting the state enterprises into private hands to solve the economic problems of the country, unconditional closure of unprofitable factories, and supported the view that women should be allowed to have an abortion in the early days of pregnancy [Markowski and Toka 1993 [1995]]. The 2005 election showed that PiS could push the SLD out of office by referring to economic issues important to Polish voters and to the corruption in the market economy while at the same time devaluing the non-economic issues previously important to SLD voters. Similarly, the corruption associated with the market economy, resonated in the minds of voters as the failure of economic liberalism. PiS thus consolidated its supporter base using buzzwords like 'law', 'order', and 'corruption' [Szczerbiak and Taggart 2008] against the degeneration that took hold during the Polish transition.

Markowski and Toka [1993 [1995]: 85] defined three relevant political attitudes in Poland: Christian-nationalist, liberal, and rightist attitudes after the regime change. The liberal attitude comprises: a) pro-market economic attitudes and b) liberal socio-cultural opinions. The Christian-national attitudes are characterised by: a) an anti-market economic outlook and b) anti-liberal socio-cultural outlooks. The rightist attitudes comprise a) pro-market economic attitudes and b) anti-liberal, social and cultural outlooks. Thus, the growth in popularity of the 
SLD stemmed from the shift in Poles' attitudes in mainly one direction: liberalism versus Christian-national anti-liberalism. In other words, it was not a predominantly 'leftist' socio-economic ideology in Polish society that caused the growth in support for the SLD. According to Markowski and Toka, the PSL and other non-Solidarity parties (e.g. Samoobrona) disproportionately benefited from the expansion of economically populist attitudes among Poles regarding the economy. In the absence of a left-wing party that would be concerned with social equality and welfare, Christian-nationalist-peasant parties substituted for the left in the politics of social equality starting in the mid-1990s. The failure of the SLD to respond to the demands of the electorate to solve income differences and corruption (CBOS Polish Public Opinion Survey in June 2003) brought PiS to power with its promises to fight post-communist crimes of economic liberalism and to forge a strong state to cure the domestic sources of injustices of economic liberalism.

In their seminal essay on the initial victory of the SLD in 1993, Markowski and Toka concluded that the advantageous circumstances for the secular-left type parties, arising from the radicalisation of the social and cultural background, would not last for long. Along with the failure of the SLD camp, the ideological confusion of the 'Solidarity' discourse also contributed to the ascendance of the conservative forces in Poland. The prevailing conviction of Solidarity was that the 'West', seen as the only alternative to Soviet domination for Poland, was by definition 'capitalist' and hence 'anti-socialist'. Therefore, to be patriotic or 'politically correct' in an anti-communist or non-communist environment meant being capitalist (see Markowski in Zarycki [2000]). The Polish picture shows that where there is economic weakness, and particularly where the state lacks the capacity for economic management or the provision of welfare, a representation gap regarding public preferences will open up [Whitefield 2006: 737].

Also central to conservatism in Poland is the alliance between the Roman Catholic Church and the national opposition in their struggle against foreign centres. To follow this tradition, PiS underlined its Euroscepticism with criticism of the cosmopolitan features of European integration and its libertarian proponents in Poland. In this respect, it is safe to say that there was no social liberalisation in Poland in the first place because of the Catholic Church. However, a closer glance at the ascendance of PiS demonstrates that the critics of economic liberalisation also gained an opportunity to repeal political liberalism.

\section{Manifestations of the conservative shift in Poland}

The return of the welfare state in Polish political discourse

The human costs of economic transition are high. The privatisation of state enterprises and the introduction of market prices, as well as competition from imported Western goods, resulted in high unemployment and income inequality in Poland after 1989 [Paczynska 2005: 586]. As I showed above, general feelings of 
economic inequality are associated with the power and informal links of the elite, who also made disproportionate gains from the privatisation of state enterprises - an important feature of economic liberalism in the region. A sense of economic inequality goes hand-in-hand with low levels of satisfaction with democracy and freedoms. As the CBOS survey results above show, in Poland unfair competition from the West and the sale of state industries to foreigners became associated with neo-liberal impulses. Wałęsa put it very simply: under communism, people had security but no freedom, now they have freedom and hanker after security. Then they had enforced equality, now one person is a millionaire while others are in the gutter. And he adds that millionaires did not make their money in the cleanest way [Garton Ash 2006].

The EU membership negotiation phase did not see much discussion with respect to work conditions and remuneration or social welfare arrangements in the accession states. Foreign investors and national governments often collaborated to preserve the specific competitive advantage of the new member states, promoting the social differences between East and West as incentives for investment [Bohle 2005]. In this respect, the West came to stand for Western countries, international financial organisations, as well as the EU [Szalai 2001]. In Szalai's [2001] words, this 'alliance built between the political elite of the accession states and the Western political and economic elite' ended up excluding the citizenry at large from the prosperity that the transition brought. Unlike Poland's Europeanising elite, however, Lech Kaczyński was able to make it clear that he would use his presidential power to veto all attempts at further liberalising the Polish Labour Code [European Industrial Relations Observatory Online 2005]. And such statements certainly helped the electoral success of PiS. According to PiS's conservative rhetoric, the conditions under which Poland joined the European Union were not good for the country's economic development (International Herald Tribune, 25-26 March 2006). This was the message that public opinion surveys were already sending in the late 1990s, and PiS responded to the message from the polls with staunch criticism of liberalism. Overall, PiS profited from the blurred picture of the EU, which the party portrayed as the source of neo-liberal economic reforms, making it the key culprit in the discourse on westernisation.

During the 2005 election campaign, Kaczyński perfected use of the word 'liberal' in a negative context, implying - and often openly declaring - that the liberalism of his main rival from the PO, Donald Tusk, would only benefit the rich. Lech Kaczyński stressed that it was the responsibility of the state to forge greater solidarity between those who have succeeded in the new capitalist Poland and those who have not. While in government, PiS brought various institutions on board the moral revolution it was promising. The establishment of a grand 'Truth and Justice Commission' to probe all the scandals of the post-1989 era was the first step [Kosc 2005b]. It was conceived as a response to the belief shared by many ordinary Poles that anyone who is rich must be a thief or a cheat (CBOS July-August 2001) and thus to the corruption associated with economic liberalism. 
More controversially, in April 2006, PiS launched the 'Commission for Tracking Crimes against the Polish Nation' (Le Monde, 27 June 2006). It was the task of this commission to inspect the political past of Polish politicians. One of the first politicians to resign was Zyta Gilowska, the liberally oriented Minister of Finance, who was confronted with growing suspicions that she had collaborated with the secret service under communism. ${ }^{1}$ Finally, PiS established the 'Central Office of Anti-corruption' in order to audit all company finance, including EU funds. By law it is within the authority of the prime minister, not the Sejm, to appoint the head of this office, which raised doubts regarding its neutrality. ${ }^{2} \mathrm{Fi}-$ nally, the president signed legislation to start an investigation into the political backgrounds of 400000 civil servants, including school teachers and journalists (HetiVálasz, 23 November 2006). ${ }^{3}$ It was not just PiS's assault on the liberalism of the 1990s in Polish politics recounted above that drew interest, but the way in which PiS carried out the process. When the anti-corruption agency men struck, arresting everyone from allegedly crooked politicians to surgeons suspected of taking bribes from patients, they did it on television, wearing masks and dressed head to toe in black (The Guardian, 18 October 2007).

PiS thus manifested itself as the judge of the legitimacy of the social order that succeeded real socialism. The Kaczyński brothers insisted that not enough had been done after 1989 to make a public reckoning with the communist past, to purge the security services, and to remove from public life the people who took part in the repression of the communist regime. That was how PiS usurped what Zarycki [2000: 859] previously referred to as the cultural cleavage in Polish politics over the communist past in an attempt to discredit the post-1989 political elite, while ascribing itself a moral duty to carry out lustration. In the absence of morality, the Polish state was left in crisis: it became weak, bloated, inefficient, and very prone to corruption. PiS presented a 'Bermuda quadrangle' of corrupt politicians, secret police operators, businesspeople, and criminals. The Kaczyński brothers and their advisers deftly combined these popular themes in their calls for a 'moral revolution' in Poland in order to restore 'law' to the Polish state and 'justice' to Polish society [Garton Ash 2006]. Combating corruption is no obstacle to the implementation of the EU acquis. Yet, it is fair to ask how the PiS government failed to implement the EU acquis on rights and freedoms while opposing economic liberalism?

1 The court declared Gilowska formally innocent. The court did not find any written authorisation of recruitment nor did it find any reports. For further details of the case, see Chodakiewicz [2006], Retrieved 25 September 2006. http://www.worldpoliticsreview. com/article. aspx?id=205

2 The office can paralyse companies by asking too much or forcing them to go through an audit period of almost nine months. It is up to the politicians to decide which companies to check. See 'Można ... Antykorupcyjne.' (http:// wiadomosci.onet.pl/1345117,11,1,1,item. html).

${ }^{3}$ The Polish Constitutional Court later declared that the legislation was unconstitutional and the law was struck down in April 2007. 


\section{Diminishing political and civil rights}

When women and men regained their civic liberties after the change in regime in the post-communist countries, there was a naïve expectation that freedom and opportunity to act would grow and empower all citizens. It is apparent that this has not been the case [Chimiak 2000: 4] and the problems involved in securing gender rights illustrate the difficulties of implementing the human rights acquis. Under PiS, however, Poland was the accession state with the most significant implementation problems.

Poland transposed the EU legislation on equal treatment for men and women and created an anti-discrimination watchdog as required by the EU by 2003. However, one of PiS's first acts was to do away with the position of a gender-equality ombudsperson. The government said it would assign the anti-discrimination brief to a lower-ranking official [Kosc 2005c]. The nomination of the Ombudsman for Human Rights was also not without controversy: Dr. Janusz Kochanowski's nomination raised concerns about his objectivity and independence from the political ideas of his backers since he had been a candidate for the European Parliament under PiS in 2004. The Polish Federation of Women and Family Planning characterised the new officeholder as a highly controversial lawyer, known for his controversial approach to human rights, his well-known support for capital punishment, and his low tolerance for homosexuals. ${ }^{4}$

After its EU membership, the Polish attitude towards population control also became crucial even beyond the EU proper. The fact is that the EU member states provide over two-thirds of the core funding for the United Nation's Population Fund (UNFPA). The European Commission also contributes to more specific programmes. ${ }^{5}$ The position of Poland on these contributions could determine the future policies of UNFPA. An exhibition organised by conservative right-wing Polish Members of the European Parliament (MEPs) on the premises of Parliament revealed where the participating Polish MEPs stood as regards birth control. The exhibition titled 'Life and Children in Europe Official Opening of the Exhibition', expressed opposition to abortion and the undertone of the exhibition was a comparison of women aborting children to people killing each other in peace time, backed up with quotations from Mother Theresa and pictures from concentration camps.

At this point, it is necessary to examine the position of the Catholic Church in Polish politics and the attitude of the Polish Catholic Church towards the EU.

\footnotetext{
${ }^{4}$ See Wanda Nowicka, 'Disturbing Nomination.' Polish Federation for Women and Family Planning. http://www.federa.org.pl/?page=news\&newsid=71\&lang=2 (27 January 2006).

${ }^{5}$ See http://www.unfpa.org/eu_partnership/index.htm. While the conservative circles accuse UNFPA of promoting abortion under the guise of promoting 'sexual and reproductive health services', the UNFPA website explicitly notes that the organisation does not promote abortion. See http://www.lifesite.net/ldn/2005/jul/05070404.html as an example of conservative criticisms of the UNFPA.
} 
Catholicism not only substantiated the ideology of PiS and its coalition partners in Poland, but also framed the way they approached gender rights. The politically active position of the Catholic Church drew criticism, sometimes even from the Vatican itself. While paying an official visit to Poland in May 2006, Pope Benedict XVI stated that Catholics expected their priests to mediate just the relationship between God and human beings. But they do not expect priests to be experts on the economy or politics (Magyar Hirlap, 26 May 2006). Still, neither the Polish past nor present can be understood without grasping the complexity of the Church's presence and moral force in Poland, its notions of both the individual and the social order, its mixture of conservative ethics and progressive and nationalist politics, and the ongoing battle between Church and state - which both preceded and followed forty years of authoritarian communism [Davies 2001: 299-300].

As part of the dissidence movement, the Episcopate of the Roman Catholic Church along with radical intellectuals introduced Helsinki norms into constitutional debates. In the post-1989 period, however, the influential Catholic Church has sometimes been a challenge to Poland's European project. The Church perceives Western Europe as the source of secularisation, privatisation of religion, liberalisation, and the loosening of family values and national traditions, and sees it as a threat to Catholic values and traditions in Poland. In this connection, on 21 March 2002 the Polish Episcopate issued an official document titled [Konferencja Episkopata Polski 2002], according to which the Catholic Church is

supportive of unifying initiatives which respect those fundamental human rights that minister to the integral development of human beings and promote the common good of both nation and country [...] the Universal Church and Catholic Church in Poland have been supportive of this process from the beginning. Europe in the eyes of the Church is not purely an economic and political structure, but primarily a historical and cultural community based on lasting ideas and tradition of JudeoChristian spiritual values, Roman law and Greek philosophy [...] The resolutions worked out by the Convention to guarantee the fundamental right to life of every human being from conception until their natural death and the right of marriage as a permanent relationship between a man and a woman (Polish Bishops on European Integration).

The definition of marriage is contained in the 1997 Polish Constitution and the Church fears that under European Union law this provision might be challenged. Similarly, the Church is afraid that European integration may throw the door wide open to a weakening of the strict Polish anti-abortion law or even its complete liberalisation.

Such ideas have been strongly articulated by Radio Maryja, a nationwide network that reaches as many as four million regular listeners and enjoys a virtual monopoly on Catholic broadcasting in Poland. It became the focal point of anti-EU resistance during the late 1990s. The radio station and its newspaper out- 
lets were instrumental in securing Sejm seats for the LPR. Regarding the broadcasting of Radio Maryja, the Polish writer Andrzej Stasiuk wrote the following in L'espresso:

\begin{abstract}
I listened to Radio Maryja with strange fascination some time ago. Mostly, I listened to it at night when it went to a certain wave of phone conversations directly with the listeners. Prior to that, I had never listened to anything like that on any radio or television. Simple people, the most ordinary people, called in. Poor, lonely, old people; from small villages in the provinces; pensioners, disabled, unemployed. All the colours not considered by other programmes of broadcasting agencies; all those absent, forgotten, disadvantaged, and non-existent in the new, fantastic market economy. There were voices that we could hear on the bus, on the street, in the waiting rooms of hospitals, in the used-clothing stores, in the cheap food stores. They called the radio and talked sincerely about their lives, about loneliness, their feeling of becoming useless. They talked about their own misery and sadness. They talked to Radio Maryja because no one else wanted to listen to them [Stasiuk 2006].
\end{abstract}

That was how Radio Maryja earned an active position in Polish politics as the public space. In comments that would have gone well with Radio Maryja's audience, the prime minister of the first PiS-led government, Marcinkiewicz, told the station that his government would stand firmly against abortion, in vitro conception, and contraceptives. Marcinkiewicz also stated that he was not afraid of the European Union's pressure to liberalise abortion policy [Kosc 2005a].

Beyond Radio Maryja, the voice of the Catholic Church can be overrepresented in the Polish media. The Media Act (Article 18.2) requires 'respect for Christian values'. The Catholic Church is the only body outside the 'National Radio and Television Broadcasting Council' authorised to re-license radio and television stations to operate on frequencies assigned to the Church [Reporters without Borders 2003; US Department of State 2005]. During the accession talks, the European Commission remained silent on this issue and did not assess the Polish Media Act as a constraint on freedom of expression. PiS politicians made the best of the Catholic domination of the Media Act and demonstrated their intolerance of criticism. The Kaczyński brothers also showed their intolerance of criticism when the President cancelled attendance at a meeting between the Polish, German, and French presidents in Weimar intended to mark the 15th anniversary of the Weimar Triangle ${ }^{6}$ and asked for an official apology from the German government in response to a satirical report about them in Tageszeitung.

Statute 132 was passed by the government of former Prime Minister Jarosław Kaczyński in 2006. It slaps a three-year prison term on anyone 'publicly accusing the Polish nation of participating in, organising, or being responsible for Nazi or Communist crimes'. Jan Tomasz Gross, known for his critical stance on the role of the Poles during the Holocaust, was accused of slandering the Polish nation with

${ }_{6}$ Polskie Radio. http://www.polskieradio.pl/polonia/article.asp?tId=38784\&j=2. 
his new book Fear, which probes the murder of Jews in Poland after the end of the Second World War. In January 2008 the author came under investigation from public prosecutors in Krakow, where his publisher, Znak, is based. The prosecutors looked into whether the book broke the law that makes slandering the Polish nation a crime (Der Spiegel Online, 18 January 2008). Yet, the existence of such a statute in an EU state was reminiscent of the previous, infamous Penal Code 301 in Turkey that made slandering Turkishness a crime.

Beyond freedom of expression, discrimination against sexual minorities in Poland became a major case of the EU's failure to get its human rights legislation introduced in full in a member state. In this area as well, there is visible influence of the Catholic religion to demonise homosexuals as sick people. Yet, the conservatism of PiS triggered a reaction to political liberalism that went beyond traditional Catholic conservatism.

The European Union has already stated that discrimination on the basis of sexual orientation may undermine the achievement of the objectives of the EC Treaty in the Preamble of the Amsterdam Treaty. According to the Lambda Warszawa Association, there are many cases of discrimination against sexual minorities in Poland [Abramovicz 2007]. These cases of discrimination relate to welfare provisions, rights of inheritance, limitations on the constitutional rights of lesbians and gays to express their opinions and to receive and distribute information. The latter stems from the obligation of the mass media to respect the 'religious beliefs of the audience, and in particular the Christian system of values', which, as noted above, are often hostile towards homosexuality [Reporters without Borders 2003]. Another level of discrimination relates to the existence of regulations which make appointments to certain functions or the performance of certain professions dependent on the undefined criteria of 'integrity' and 'high morals' [Lambda Warszawa Association 2005]. To deny someone a certain job on the basis of some characteristic that has no bearing on his/her ability to carry out the requirements of this job is one of the most sophisticated ways in which to degrade a person or make him/her feel worthless [Mohr 1997].

President Lech Kaczyński and the former Prime Minister Kazimierz Marcinkiewicz pledged to take action against discrimination targeting gays. But in an interview shortly after his appointment, Mr. Marcinkiewicz described homosexuality as 'unnatural' (BBC News, 12 June 2006). Previously, as the mayor of Warsaw, Lech Kaczyński had banned an 'equality parade' for gays and lesbians [Garton Ash 2006]. He took a firm stance against homosexuals, who - he claimed - were 'spreading an inappropriate lifestyle' and he could not see any justification for propagating homosexual culture [Kosc 2005d]. The mayor of Poznan followed Kaczyński's example and also banned a parade in November 2005. The organising committee of a gay pride parade in Poznan appealed at the Provincial Administrative Court after they were refused the necessary permission to organise it. The Provincial Administrative Court explained why 'equality parades' constitute a part of freedom of expression. In response to the appeal against the decision of the Mayor of Poznan and the Governor of the province, the court stated that the 
aim of freedom of assembly is not only to grant independence and self-fulfilment to individuals, but also to protect the social communication processes necessary for the proper functioning of a democratic society. Public interest is the underlying factor of this protection. Freedom of assembly, apart from its public-legal aspect, belongs to the basic, fundamental political rights of humans [Śmiszek 2007]. The court's decision thus affirmed that the right to organise 'gay parades' was central to freedom of assembly and therefore a fundamental aspect of human rights. Later, the European Court of Human Rights unanimously ruled in the 'Case of Baczkowski and Others v. Poland' that the banning of gay parades in Poland was in violation of Articles 11, 13, and 14 of the European Convention on $\mathrm{Hu}$ man Rights and therefore it contravened freedom of assembly and association. ${ }^{7}$

In reference to the situation of homosexuals in Poland under PiS, a Labour Member of the European Parliament, who is also the president of the European Parliament's Intergroup on Gay and Lesbian Rights, Michael Cashman, stated that 'we are fighting battles that we thought we had won years ago in Europe once again' (International Herald Tribune, 24 November 2005). While the European Parliament passed a 'Resolution on the Increase in Racist and Homophobic Violence in Europe', it still sounded rather weak with respect to the situation in Poland, and was diluted by the grouping of various crimes in one resolution. ${ }^{8}$ Nevertheless, the response from the Polish Parliament was very vocal: the Sejm passed a counter declaration, expressing the view that the European Parliament, which apparently made no particular independent study of the situation in Poland, does not know what it is talking about. Article 51 in the European Charter of Fundamental Rights and Freedoms underlines the fundamental responsibility of the member states with regards to implementing the norms of the Charter. Poland cannot be an exception.

In turn, Marcinkiewicz, in an interview, characterised the rights and freedoms embedded in the European system as 'ideologised'. In response to a question about the rights of homosexuals in Poland and statements from certain politicians in his party regarding the re-introduction of capital punishment, Marcinkiewicz stated that the Polish Constitution guaranteed the rights of every citizen, and the institutions of democracy - the government among them - are the guardians of these rights. However, he continued, the Constitution also guaranteed the rights of families -understood as a relationship between a man and a woman. That was why he emphasised the need to protect families as a constitutional duty (Magyar Hirlap, 17 January 2006).

\footnotetext{
7 See 'Case of Baczkowski and Others v. Poland.' European Court of Human Rights. http://cmiskp.echr.coe.int/tkp197/view.asp?item=1\&portal=hbkm\&action=html\&highli ght=Baczkowski\%20\%7C\%20poland\&sessionid=7659111\&skin=hudoc-en (3 May 2007). ${ }^{8}$ See 'MEPs Adopt Resolution on the Increase in Racist and Homophobic Violence in Europe.' European Parliament. http://www.europarl.europa.eu/sides/getDoc.do?pubRef=//EP//TEXT+IM-PRESS+20060608IPR08828+0+DOC+XML+V0//EN (15 June 2006).
} 
Marcinkiewicz's ideas in particular and the stance of conservative rightwing politicians in Poland in general show how the dominant group sees itself as the embodiment of universal values, which express 'truth' and 'justice' in an absolute sense. In this context, all other groups can be described as different, where different means deviant and therefore inferior treatment is justified [Fraser 1996]. This attitude expresses the outlook on gender relations in Poland. Also prevalent has been the use of the neo-liberal option for economic change as the only solution to the economic crisis in Poland after the 1990s [Gowan 1995, 2005]. The liberal reformers presented neo-liberalism as the only solution to the country's economic ills and regarded anyone who did not belong to their clique as useless [Ost 2005]. So far, these two prevalent perspectives in Poland have gone hand-in-hand owing to elite dominance in politics and the relative silence of the EU during the accession negotiations.

\section{Explaining the conservative shift in Poland}

During the decades in which Poland was consolidating its democracy, the advocacy of democracy became very closely tied to the endorsement of neo-liberal ideas about state-society relations - in particular, reliance on the market to guide economic priorities, minimisation of the social role of government, and encouragement of the maximum privatisation of economic life [Ost 2005]. The transition experienced pressure from the World Bank and the International Monetary Fund to build a high-growth economy, and the result was still the partial social disempowerment of the state. At the beginning of the transition in Eastern Europe, the European Union did not produce any alternative rhetoric to the demands made by international financial institutions on the accession states [Gowan 1995], despite its parallel attempts to install 'social Europe', while instituting a competitive economic system. Polish politics is a crucial example of the complex confluence of political conservatism, with Catholic themes and economic liberalism as contingent factors affecting the institutionalisation of human rights.

Critics of European integration accused the EU of having an economic programme that favoured only economic freedom and competition. In this light, the critics designed the Treaty of Rome as an economic neo-liberal constitution, the aim of which was to protect market freedom from public power. However, European integration was also conceived as a safeguard of the welfare state. In the latter perspective, the European Union is a new forum in which social rights, which are no longer viable at the national level owing to economic competition among states, are re-introduced. Therefore, looking at the balance between economic freedom and social rights in the EU, we find a very broad conception of social rights. They include provisions that do not have the status of fundamental rights in national constitutions [Maduro 1999: 449]. However, it is very difficult for the EU to make member states abide by these provisions and the Commission Reports on Poland prior to its accession demonstrate this inability. 
The ensuing economic problems in the new member states also show that the EU accession did not necessarily offer solutions to the social and financial problems associated with the transition to a market economy. While EU integration has brought accelerated economic growth to the new member states, the level of economic inequality is also increasing. Economic development is ultimately advantageous for the bigger cities, but its effect is less significant for the smaller towns and the countryside [Eurostat Regional Yearbook 2007].

There has been little expectation among the Polish population that joining the EU would solve poverty. On the eve of accession, $46 \%$ of respondents in one survey expected that poverty levels would most likely increase after Poland became a member, while only $16 \%$ anticipated that EU membership would decrease poverty levels. Those with less education and living in small towns and the countryside tend to be more critical of the changes and more nostalgic for socialism [Paczynska 2005: 590, 597]. These 'losers' in the transition process comprise the core of PiS voters and hence anti-liberalism finds resonance among Polish voters.

Nevertheless, initially Polish liberalism did not mean just market capitalism. Ost [2005: 98] writes that liberalism also meant 'promoting gender equality and minority rights, or at least recognising that such values were now a requisite part of the (pro-Western) world order. It meant anti-racism and, for most, an acceptance of gay rights.' Nonetheless, the crucial point is that the liberals promoted political liberalism as tied to the defence of economic liberalism. All the grand ideals of human rights and civil society, they believed, depended first and foremost on the eradication of state ownership and government subsidies and the introduction of a capitalist economy with hard budget constraints. That was how, over time, political liberalism simply became secondary for Polish liberals and the ideals of the neo-liberal market economy became the dominant discourse. In this article I argue that this gave ample opportunity to their opponents from the conservative camp to reject both the goals of economic and political liberalism in one package. PiS excelled in offering counter-liberalisation on both the political and economic fronts.

Ost [2005: 99, 101, 114] argues that in Poland the liberals got it wrong: it is not capitalism but the way capitalism is challenged that underpins democracy. In the end, political liberalism is endangered by tying it too closely to economic liberalism. Therefore, although the new post-communist elite sought to create both a democratic polity and a capitalist market economy, it saw only the second of those aims as especially difficult. That was how their approach became disingenuous, ineffective, and detrimental to the consolidation of liberal politics. Finally, the liberals lost when they squandered their moral and political authority by adopting such a hostile attitude to their labour base; they created a base that came to identify political liberalism with arrogance on the one hand and economic liberalism on the other. In the end social exclusion became closely linked to economic exclusion and thus poverty.

The failure of liberalism to bring about equal opportunities in Poland since the beginning of the regime change and its recoiling from an active state brought 
to power a political party that wished to correct the wrongdoings of the transition. At the same time, issues such as sexual orientation and gender rights were let out of the closet. The liberalism intrinsic to the Polish transition provided the representatives of gay-lesbian and women's rights with chances to instigate broadly based debate and contestation. Yet, what was missing from this debate was criticism of economic liberalism as regards increasing poverty and inequality. As Ost [2005] states, these criticisms came from the populists with conservative political ideas.

The result is that people dismissed the promises of political liberalism and turned towards conservative parties with the hope of seeing an active state to correct inequalities and corruption. In this way the failure of economic liberalism contributed to conservatism with Catholic undertones against the implementation of human rights norms. This is not to say that up until PiS's ascendance to power gender rights were guaranteed. Nevertheless, what is clear is that the ascendance of PiS to power put these rights more at risk. And even Poland's EU membership failed to secure the full implementation of human rights owing to the PiS factor in Polish politics. The 2007 elections brought defeat to PiS, but the party simultaneously saw an increase in the number of votes it received.

Difference in opinion on various issues is nothing new to the member states of the Union; it is almost more the norm than it is a novelty. Nevertheless, adhering to the highest standards of human rights is a fundamental requirement for accession to the EU. While issues such as social rights and gender rights do not fall under the most basic definition of human rights [Falk 2000], they still compose a fundamental part of the EU human rights acquis. It is significant that in June 2006 the organisers of Warsaw's annual 'Equality Parade' for gay rights wore t-shirts which read 'Europe=Tolerance' (BBC News, 12 June 2006). The unanimous decision that the European Court of Human Rights reached in the case of Baczkowski and Others v. Poland showed that the court considered gay parades fundamentally related to freedom of expression. Given the extent of human rights problems in Poland in the area of gender rights, the President of the EU Commission, Manuel Barroso, felt the need to emphasise anti-discrimination on the basis of sexual-orientation in the EU acquis. During ex-Prime Minister Marcinkiewicz's visit to Brussels, Barroso said that in EU member states the Charter of Human Rights is the standard, and it states that everyone has the right of assembly, regardless of sexual orientation (Figyelö, 1-7 December 2005).

\section{Conclusion}

Using the example of PiS in Poland, this article demonstrated that populist conservative political parties oppose liberalism - both economic and political - as a package in the new EU member states by drawing attention to the discontent that was caused by the transformation to and consolidation of neo-liberalism in the CEE states. In order to support this argument, I described the political pic- 
ture in Poland before PiS's electoral victory. I showed the popular reactions and responses to the issues that in the public mind were associated with the market economy, such as privation, corruption, and the undeserved prosperity of the elite. My discussion of the reaction of PiS to political liberalism rested on my observations of the rhetoric of its leadership on gender rights and freedom of expression. I consider both of these issues as significant components of the political liberties required for EU membership.

The article does not test the relative importance of the economic and political aspects of the EU acquis against each other, but assesses them as issues of equal importance and weight in the enlargement process. Similarly, in discussing the impact of the failure of economic liberalism to instigate a reaction to the all-encompassing liberal agenda of the EU, I do not seek to detach the domestic and the international causes of such a failure. Rather, I approach the issue of such a failure from the point of view of the respondents of opinion polls in order to show it was not necessarily the identifiable causes but the whole process of fraud, the undeserved prosperity of the elite, degeneration, and the corruption associated with the economic transition that contributed to their reaction. I situated PiS as a reactionary force to liberalism in one package and illustrated how its reaction to economic liberalism forged more conservatism in Poland. In effect, the conservatism of PiS became specific for the way in which it used the narrative of failed transformation to curtail political liberties.

The Polish case of PiS should offer a warning to the proponents of a competitive market economy in the western Balkans and the Middle East as a precondition for democracy. If differences and rifts have already appeared between the 'old' and the 'new' members of the EU in a matter of only a few years since enlargement, this could suggest that the Copenhagen criteria for accession are not adequate and comprehensive enough to prepare the accession countries for EU membership. The growing distance between Brussels and Warsaw under the PiS-led coalition government was a major blow to the continuance of Copenhagen criteria. The article showed that, despite the various problems of social and gender rights in Poland even prior to accession, the EU kept a close eye on many issues. The EU should therefore re-define its accession conditions before it starts to consider enlargement towards countries with more serious human rights and economic problems, such as Turkey and Croatia.

UMUT KoRKuT is a research fellow at University College Dublin, School of Politics and International Relations. He was awarded a PhD in political science from the Central European University. His most recent publications include 'Micro and Macro Development in Hungary under the Glance of the EU Cohesion Funds', East European Quarterly, December 2008, 'The 2006 Hungarian Election: Economic Competitiveness versus Hungarian Solidarity', Parliamentary Studies, September 2007, 'Die Konsolidierung des Kapitalismus und die Neue Armut in Ungarn' in Buzogány Áron and Frankenberger, Rolf (eds.), Weltregionen im Wandel. Mittel- und Osteuropa, Baden-Baden: Nomos 2007. 


\section{References}

Abramovicz, Marta. (ed.) 2007. Situation of Bisexual and Homosexual Persons in Poland 2005 and 2006 Report. Warsaw: Lambda Warsaw Association.

Bohle, Dorothe. 2005. 'The EU and Eastern Europe - Failing the Task as a Better World Power?' Pp. 348-361 in Socialist Register, edited by Leo Panitch and Colin Leys. London: Merlin Press.

Bugyinszki, György. 2006. 'Kampányüzenetek.' Népszabadság Hétvége, 29 April.

Cortell, Andrew P. and Jame W. Davis. 2005. 'When Norms Clash: International Norms, Domestic Practices, and Japan's Internalisation of the GATT/WTO.' Review of International Studies 31(1): 3-25.

Chimiak, Galia. 2000. 'Bulgarian and Polish Women in the Public Sphere.' International Feminist Journal of Politics 5: 3-27.

Chodakiewicz, Marek Jan. 2006. 'Zyta or "Beata": The Convoluted Case of Poland's Deputy Prime Minister.' World Politics Review, 25 September 2006 (http://www.worldpoliticsreview.com/article.aspx?id=205).

Davies, Norman. 2001. Heart of Europe. The Past in Poland's Present. Oxford: Oxford University Press.

European Industrial Relations Observatory Online. 2005. 'The NSZZ Solidarity Backs Up Candidate for President of Poland.' EIRONLINE, 10 October 2005 (http://www.eurofound.europa.eu/eiro/2005/10/inbrief/pl0510101n.htm).

Eurostat Regional Yearbook 2007. 2007. (http://epp.eurostat.ec.europa.eu/cache/ ITY_OFFPUB/KS-AF-07-001-05/EN/KS-AF-07-001-05-EN.PDF).

Falk, Richard A. 2000. Human Rights Horizons. The Pursuit of Justice in a Globalizing World. New York and London: Routledge.

Fraser, Nancy. 1996. 'Social Justice in the Age of Identity Politics: Redistribution, Recognition and Participation.' Tanner Lectures on Human Values, 30 April - 2 May.

Garton Ash, Timothy. 2006. 'The Twins' New Poland.' The New York Review of Books, 9 February 2006 (http://www.nybooks.com/articles/18678).

Gowan, Peter. 1995. 'Neo-liberal Theory and Practice for Eastern Europe.' New Left Review 13: 3-60.

Gowan, Peter. 2005. 'Pax Europæa.' New Left Review 34 (July-August): 134-144.

Konferencja Episkopata Polski. 2002. 'Polish Bishops on European Integration.' 21 March 2002 (http://209.85.129.132/ search?q=cache:IFwTx4JP5FUJ:www.episkopat.pl/ \%3Fa\%3DdokumentyKEP\%26doc\%3Dbiskupi_eng-21032002+polish+bishops+on+ european+integration\&cd=1\&hl=en\&ct=clnk\&client=firefox-a).

Korkut, Umut. 2007. 'The 2006 Hungarian Election: Economic Competitiveness versus Hungarian Solidarity.' Parliamentary Affairs 60 (4): 675-690.

Kosc, Wlodzimierz. 2005a. 'Poland: Law and Justice for All.' Transitions Online, 21 November.

Kosc, Wlodzimierz. 2005b. 'President Kaczyński: The Soft Conservative.' Transitions Online, 24 October.

Kosc, Wlodzimierz. 2005c. 'Poland: Law and Justice for All?' Transitions Online, 21 November.

Kosc, Wlodzimierz. 2005d. 'Poland: Taking it to the Streets.' Transitions Online, 13 June.

Lambda Warsaw Association. 2005. Report on Discrimination on Grounds of Sexual Orientation in Poland.

Maduro, M.P. 1999. 'Striking the Elusive Balance between Economic Freedom and Social Rights in the EU.' Pp. 449-472 in The EU and Human Rights, edited by Philip Alston. Oxford: Oxford University Press. 
Markowski, Radoslaw and Gábor Tóka. 1993 [1995]. 'Left Turn in Poland and Hungary Five Years After the Collapse of Communism.' Sisyphus 9 (1): 75-99.

Markowski, Radoslaw. 1997. 'Political Parties and Ideological Spaces in East Central Europe.' Communist and Post-Communist Studies 30 (3): 221-254.

McManus-Czubińska, Clare, William L. Miller, Radoslaw Markowski and Jacek Wasilewski. 2003. 'The New Polish Right.' Journal of Communist Studies and Transition Politics 19 (2): 1-23.

Mohr, Richard. 1997 'Millian Arguments for Gay Rights.' Pp. 247-251 in The Human Rights Reader, edited by Micheline Ishay. New York: Routledge.

Ost, David. 2005. The Defeat of Solidarity Anger and Politics in Postcommunist Europe. Ithaca and London: Cornell University Press.

Paczynska, Agniezka. 2005. 'Inequality, Political Participation, and Democratic Deepening in Poland.' East European Politics and Societies 19 (4): 573-612.

Pridham, Geoffrey. 2008. 'Status Quo Bias or Institutionalisation for Reversibility?: The EU's Political Conditionality, Post-Accession Tendencies and Democratic Consolidation in Slovakia.' Europe-Asia 60 (3): 423-454.

Reporters without Borders. 2003. Poland-Annual Report.

Schimmelfenning, Frank, S. Engert and H. Knobel. 'Costs, Commitment and Compliance: The Impact of EU Democratic Conditionality on Latvia, Slovakia and Turkey.' Journal of Common Market Studies 41 (3): 495-518.

Szczerbiak, Aleks and Paul Taggart. (eds.) 2008. Opposing Europe. The Comparative Party Politics of Euroscepticism. Oxford: Oxford University Press.

Śmiszek, Krzysztof. 2007. 'Changes in the Legal Situation of Homosexual Persons in Poland.' Pp. 409-427 in Situation of Bisexual and Homosexual Persons in Poland 2005 and 2006 Report, edited by Marta Abramovicz. Warsaw: Lambda Warsaw Association.

Stasiuk, Andrzej. 2006. 'A Varsawvia....Evo.' (Poland Governed by the Extreme Right) L'espresso. 5 July 2006 (http://www.eurotopics.net/en/presseschau/archiv/ aehnliche/archiv_article/ARTICLE5623-Poland-governed-by-the-extreme-right July).

Szalai, Erzébet. 2001. 'Posztszocializmus és globalizáció Magyarországon.' Politikatudományi Szemle 10 (2): 9-14.

US Department of State. 2005. International Religious Freedom Report - Poland.

Whitefield, Stephen. 2006. 'Minding the Representation Gap Explaining Differences in Public Views of Representation in Post-Communist Democracies.' Comparative Political Studies 39 (6): 733-758.

Zarycki, Tomasz. 2000. 'Politics in the Periphery: Political Cleavages in Poland Interpreted in Their Historical and International Context.' Europe-Asia Studies 52 (5): 851-873. 